\title{
The Franks in the early Ideology of Frederick Barbarossa (1152-1158)
}

\author{
Vedran Sulovsky
}

\author{
Original scientific paper \\ UDK 32-05 Barbarossa,F."1152/1158"
}

\begin{abstract}
This article traces the Frankish legacy in the early years of Frederick Barbarossa's reign, from his coronation to the diet of Roncaglia (1152-1158). I demonstrate that Frederick's ideological system was based on a fluctuating set of German, Frankish, and Roman identities, which constituted an imperial identity. By analysing Frederick's words and deeds as reported by his contemporaries and comparing them to the Cappenberg Head which he commissioned, I conclude that Frederick alternated between these various identities based on his political situation, and that new ideological developments during his reign, such as the introduction of the term sacrum imperium, stemmed directly from the political discernment of Frederick and his court.
\end{abstract}

Keywords: Franks, identity, Frederick Barbarossa, Charlemagne

The establishment of source-based (scientific) history in the age of Ranke was no small intellectual achievement. Historians turned their eyes to the building blocks of history: source texts. While other sources can amplify our understanding of an event, a process or a structure, only the text can provide the historian with a proper intelligible narrative. Even scientific history, however, did not account for the very existence of a narrative, which has been subjected to scrutiny more recently. Thus, identity as the primary unit of narrative formation, and therefore of all historical ideologies, went mostly unnoticed by the great scholars of ideology. Though a Frankish, Roman and German Charlemagne existed side by side, for example, rulers in the post-Carolingian period were rarely 
set apart from national history proper as in the essay collection Karl der Große oder Charlemagne? (Hampe, Naumann, Aubin et al. 1935). A very peculiar case of this oversight is that of the Franks, a well-studied people whose post-imperial history has nevertheless been only rarely and inadequately studied. While the French narrative appropriates them for the creation of a French realm centred in Paris, the German narrative treats them as one of the German peoples, though they were only to become German in the late Salian and early Hohenstaufen era (Brühl, 1995).

Frederick Barbarossa's ideology in particular cannot be approached without an understanding of the political identities which were cultivated at his court. Most German scholars, who often approached Barbarossa as the last truly great "German" emperor, did not undertake an investigation into Frederick's Frankish identity, as it seemed to them more the last echo of a forlorn past than a clarion call heralding the future. His Roman identity has received similar treatment. Ranke (1881-1888) never mentioned the Franks in the parts of his magnum opus dedicated to Frederick Barbarossa, and the Frankish identity of the emperor was similarly glossed over by Giesebrecht (Giesebrecht 1855-1895). While Tellenbach (Tellenbach 1943) wrote an article tracing the Frankish identity into Hohenstaufen times in 1943, he did not carry his investigations any further. In more recent times, Brühl (Brühl 1995: 707-725) closed his monumental history of the separation of France and Germany with 1056, whereas Müller-Mertens (Müller-Mertens 1970) satisfied himself by stating that the 1110 s saw the establishment of the term "Teutonicus" for Germans all across Germany, though he added that Otto of Freising, writing his Chronicle of the Two Cities at around 1146, already had difficulties explaining how Frankish history segued into German history. Petersohn's recent work (Petersohn 2010) on Rome and the late Salian and Hohenstaufen emperors omits any Frankish identity in imperial policies. Simply put, it is as if the Franks disappeared into thin air in eleventh- and twelfth-century Germany. The purpose of this article, then, is to show the continuing relevance of Frankish identity during the reign of Frederick Barbarossa by examining the texts and cultic objects related to the longest-reigning Holy Roman Emperor of the twelfth century.

First of all, Frederick's coronation fell on the Laetare Jerusalem Sunday, a date chosen in advance by Conrad III for the coronation of his son Frederick IV, as Görich pointed out. The Laetare Sunday was part of a Hohenstaufen tradition dating back to 1134, when the brothers Frederick II of Swabia and Conrad III of Germany had to bow down before their lord Lothair III of Supplingenburg. 
Hohenstaufen coronations from 1138 to 1152 would take place on this day to commemorate their triumph over their opponents (Görich 2011: 90-95). Otto of Freising's spectacular account of Frederick's coronation points directly to the Hohenstaufen ambition to imitate Charlemagne by ascending his throne in the same Church of Saint Mary in Aachen where German kings were traditionally crowned since Otto I was crowned there in 936, with few exceptions. The description of the act of coronation itself, however, points to more than the Frankish-German tradition: Frederick was "coronatus in sede regni Francorum, quae in eadem aecclesia a Karolo Magno posita est, collocatur," (Gesta Friderici I.: 104) and "dum finito unctionis sacramento diadema sibi imponeretur," (Gesta Friderici I.: 104) after which the bishop of Münster, also called Frederick, was anointed. The whole scene reads not unlike a miracle:

Sed et hoc silentio tegendum non erit, quod eadem die in eadem aecclesia Monasteriensi selectus item Fridericus ab eisdem, a quibus et rex, episcopis in episcopum consecratur, ut revera summus rex et sacerdos presenti iocunditati hoc quasi prognostico interesse crederetur, qua in una aecclesia una dies duarum personarum, quae solae novi ac veteris instrumenti institutione sacramentaliter unguntur et christi Domini rite dicuntur, vidit unctionem (Gesta Friderici I.: 105).

God chose Frederick, his anointed, to preside over the realm of Charlemagne. Even more to the point, the king Frederick was anointed before the bishop Frederick, taking precedence in the hierarchy of the heavenly Lord's subjects. While it may seem that this sacral status of the ruler may or may not be connected to his Frankish identity, for Frederick Barbarossa a division between the two was logistically impossible, though the two did have different functions within the worldview of Frederick's court.

The earliest trace of a definite Frankish identity at Frederick's court can be found in the emperor's answer to the Roman ambassador in Otto of Freising's account of their meeting. The speeches Otto had Frederick declaim there are worlds apart from the coronation, even considering Petersohn's (Petersohn 2010: 133)caveat that they might reflect the year 1158 much better than 11541156. ${ }^{1}$ When the Roman ambassador tried to persuade the emperor to accept coronation by the people of Rome, using many ancient Roman topoi for the first time in several hundred years, Frederick erupted into a vehement speech in

\footnotetext{
${ }^{1}$ See pages $13 \mathrm{ff}$ for a discussion of Petersohn's point of view.
} 
which he enumerated all the reasons why he was to rule by God's grace alone, and not by the will of the people. In short, he said that Constantine the Great transferred the Roman Empire to Constantinople, and took the Senate there with him. As the Franks under Charlemagne conquered Rome and with it the imperium, the new Senate now consisted of the nobles of the regnum Francorum, and not those vying for primacy in the city of Rome. He added that while the Romans prided themselves on the tyrants Desiderius and Berengar, Charlemagne and Otto the Great captured them and defeated the Lombards and the Greeks. Finally, Frederick stated that he would take what was his by the grace of God, and that the Sicilians would be punished for their insolence (Gesta Friderici I.: 136139). Needless to say, Frederick was not amused by the Roman opposition to the pope, as it had always been his plan to secure the papal coronation in Rome. Following Petersohn (Petersohn 2010: 15), an utterly secular coronation, such as the coronation of Henry IV before the walls of Rome, which only Benzo of Alba (Ad Heinricum IV. imperatorem libri VII: 512-514) reported, was apparently never even considered by Frederick, even if Otto of Freising updated his sovereign's ideology somewhat. That a crown received from the people would have offended the noble Barbarossa is just one part of the explanation, but why he never considered a Rome-based imperial ideology as Otto III did a century and a half before him has yet to be answered.

Most obviously, Frederick's alliance with the German magnates, such as the Welfs, depended on consensual rule, which meant that he had to share power with his rivals if he wanted to appear just. Görich's interpretation (Görich 2011: 98-104, 127-134) of Frederick's negotiations with the magnates between the death of Conrad III and his coronation is a case in point, as is the same scholar's account of the creation of the duchy of Austria. Frederick may have wanted to give the Romans a share of his ideological powerbase, as he often claimed that to be emperor of Rome without actually ruling Rome meant that his title was an empty one, ${ }^{2}$ but a restored Roman Empire as attempted by Otto III was no longer possible for Frederick, whose kingship was more institutionalised. The crystallisation of the regnum during the late Salian period meant that Frederick's world was fundamentally different from the one described in the

\footnotetext{
2 One of the earliest examples (Gesta Friderici I.: 171-172) of Frederick insisting on his rule over Rome can be found in his refusal to receive the Byzantine ambassadors until they acknowledged him as 'Romanum principem et orbis ac Urbis dominatorem' in Würzburg September 1157.
} 
panegyrics to Charlemagne, Otto the Great and other rulers (Koch 1972: 60, 142 146). ${ }^{3}$

Frederick continued the late Salian tradition of calling upon the princes of the realm to legitimise his policies, and his response to the Romans belongs to this tradition: ultimately, Rome was transferred to the Franks, and none of its glory would be found in the city itself (Koch 1972: 141-150). A different aspect of Frederick's response has been overlooked, however: if all the glory of imperial Rome resided in the Transalpine nobility, then the effects of the donation of Constantine were utterly negated, and the popes had received no imperium from Constantine the Great. It is not difficult to conclude that the legacy of the Franks was the imperium Romanum itself, and that the translatio imperii forcefully negated any claims that the popes, the Romans, other Italians or other peoples could press upon a polity whose name was at this point still only 'Roman Empire'. Even though Frederick constantly kept mentioning the Franks in his speech, at one point he clarified that by this he meant the Germans, and more precisely the successors of Otto the Great (Gesta Friderici I.: 138).

While Frederick's succession to the Frankish legacy may or may not seem justified, it also begs the question: to what end did Frederick need the legacy of the Franks? Why did he feel the need to mention both Charlemagne and Otto the Great, the Franks and the Germans, if the two were one and the same? The Roman ambassadors were certainly acquainted with the official style of Frederick and his court, and were sure not to mistake his Franks for the French. Obviously, this was not a simple clarification to an unknowing audience, but a political message. Frederick's fascination with Charlemagne was a major theme of his reign, and it has by no means been a neglected topic (Engels 1988). His fascination with the Ottonian and Salian emperors, however, has not been studied in detail, and it is difficult to discern whether any of the 'German' emperors had a special place in Frederick's ideology or not, though Schwedler discusses Frederick's reception of previous rulers in general (Schwedler 2010). In the response to the Roman ambassadors in 1155, Otto the Great's presence is no accident, though it is the first time he was mentioned by Frederick. Already he wished to appear as the successor of the ancient Roman emperors and Charlemagne, a true Frank, but also a German, who ultimately won the imperium

\footnotetext{
${ }^{3}$ For an overview of the dramatic changes which took place from the Ottonian to late Salian eras, see Tellenbach's (Tellenbach 1988), and, more recently, Goez's (Goez 2000) work.
} 
Romanum for his people with God's grace by defeating the Lombard 'tyrant', just as Charlemagne had done before him (Gesta Friderici I.: 137). One can sense Frederick's will to imitate Charlemagne now projecting itself upon Otto the Great, who was described as having repeated the successes of Charlemagne so as to suit Frederick's purposes: to exclude Charlemagne's perceived original realm, France, from staking any claims on the empire.

While the purpose of Frederick's claim to Charlemagne's legacy against the French may seem unclear, or even dubious, it is precisely the German-French rivalry which induced Frederick to take up Charlemagne as his role model and go so far as to try 'to Charlemagne' his Saxon successor to the imperium. Although the source of Frederick's rivalry with Louis VII has largely been ignored, the opening pages of Otto of Freising's Gesta Friderici point to the major problems of Frederick's reign, including the apparently French prophecy that God would make a $C$ out of an $L$. The ' $L$ ' from the prophecy is a man inspired by the spirit of the God of the pilgrims who is now fulfilling the promise of 'the angel of his mother' to visit the city of the tetragoni, meaning Constantinople. ${ }^{4}$ This is a thinly veiled description of Louis VII, whose brother Philippe vowed to visit Constantinople, but who died before he could fulfill his vow (Gesta Friderici I.: 54). The letter C in the prophecy is tied to a man who "diverted the waters of the river" (The Deeds of Frederick Barbarossa: 26). While Otto of Freising declared the city to be the city of kings (Constantinople) and also Babylon (Cairo, judging by the twelfth century use of the name Babylon), the person $C$ was Cyrus, who once conquered the Orient and parted a river to let his army cross (Gesta Friderici I.: 9-11). A less classicising vision of the French expedition in the East was present in those days, however: Odo of Deuil mentioned a council held by the French king and nobility in Adalia, where Louis VII defended his leadership of the expedition and its continuation by claiming that they, the French, were "Et nostrorum parentum gradiamur iter, quibus mundi famam et caeli gloriam probitas incomparabilis dedit" (De profectione Ludovici VII: 130). While this is most likely an allusion to the participants of the First crusade, who were mostly French, a different thought might have been present in the mind of Louis VII: he may have been imitating Charlemagne, who saved Jerusalem from the Muslims according to the legend that first appeared in the Descriptio qualiter Karolus, a St-Denis text dating to

\footnotetext{
${ }^{4}$ Peregrini was a term often used by the Crusaders to describe themselves. Its use stems from the fact that they were not only fighting for God, but also conducting a proper pilgrimage, such as that to Santiago de Compostela. For an approach to this subject, see Hehl's work (Hehl 1999).
} 
1080-1095 (Bournazel 1986: 61). Louis VII took the cross from Abbot Suger's hand in 1147, three years after the completion of the choir of St-Denis, where a whole Dionysian programme was being created. A stained-glass window depicting the army of the first crusade was already present, but also a window depicting Charlemagne's expedition to the East (Hayward 1981: 94). To conclude, it is very likely that when Louis VII said "nostrorum parentum gradiamur iter", he meant both occasions when the French liberated Jerusalem.

While Louis VI initially did not back the cult of Saint Dionysius, later in his reign he utilised it, for example when he gathered his nobles for a campaign against Henry V in 1124. It is highly unlikely that the choice of patron saint for the campaign had nothing to do with Louis VI's proclamation that the Germans should content themselves with holding Germany, which was rightfully Louis' possession according to Suger's narrative (Vie de Louis le Gros: 116-117). Louis VI's son and heir, Louis VII, raised the Dionysian cult to even greater heights, taking the cross in front of the Basilica of St. Denis in Paris and leaving his kingdom in the hands of the able Abbot Suger of St. Denis, who symbolically represented the saint himself (De profectione Ludovici VII: 16). Louis VII failed in his Crusade, however, so it is impossible to say what could or would have happened had the Crusade succeeded. Frederick Barbarossa and many other German nobles and clerics who participated in this Crusade as vassals of Conrad III certainly took note of these French innovations, especially as Louis VII demanded that Conrad III and his nephew Frederick relinquish their possessions in Esslingen and Königsberg to the Abbey of St. Denis, their rightful possessor. Unsurprisingly, the Hohenstaufen vehemently declined to comply (De profectione Ludovici VII: 102). They understood the message of their neighbour, the king of France: he wanted to restore the realm which Charlemagne dedicated to Saint Dionysius, and have it returned to him as a fief (Engels 1988: 42-43). It is virtually impossible that these developments had no influence over the young and ambitious Frederick Barbarossa, who saw his uncle and lord degraded time and time again by the French, the Turks and the Byzantines (De profectione Ludovici VII: 90-98 et passim; Gesta Friderici I.: 64-67; Görich 2011: 74-86).

Perhaps Conrad III tried to stem the rising star of the Dionysian cult by effecting a similar position for the Holy Emperor Henry II (1002-1024) via his canonisation in 1146, but this line was seemingly abandoned by Frederick, who, though present at the tenth anniversary of the elevation of Henry II's remains in 1157, did not seem to have cared much for his saintly forbear (Balzer 2012: 296). Henry II's panegyric in Godfrey of Viterbo's Pantheon (Pantheon: 240-241), 
however, seems to offer a different picture of the whole development, though further research on the Hohenstaufen-era reception of earlier rulers has to be undertaken before any suitable hypothesis can be proposed. Otto of Freising (Chronica: 290-291), however, mentioned Henry II as a pious man and a saint, though it was only his childless death which ultimately led to the ascent of Conrad II, a ruler of Trojan descent, to the throne. This is but one of numerous occasions when Otto intertwined the histories of the Trojans and the Franks, who were the same people as the Germans of his time in his eyes. This was nothing new, as the Trojans were equated with the Franks by many other Frankish, French and German historians ever since the first appearance of the complete Trojan legend in Fredegar's chronicle (Chronica: 45-50, 59) in the seventh century. ${ }^{5}$ Otto of Freising's version (Chronica: 257) of the settlement of the Trojans in Germany under their leader Franco was a perfect parallel to the rise of Rome under Trojan exiles, but it also had a climax: after the Romans moved their imperium to Greece, God's anointed Franco-Trojan king, Charlemagne, recaptured the imperium for the West through his virtue. However, while Otto the Great brought the imperium to the Germans, his saintly successor Henry II was the last non-Trojan and non-Frankish ruler of the Roman Empire, and as such he was not the ideal patron saint for a ruler who wanted to lay claim to the Frankish and Roman traditions (Chronica: 285-287, 290-291). The utterly defeated Germans who returned from the Second Crusade needed a new patron saint, one who could stand up to the French crusading Charlemagne.

Frederick Barbarossa and his court understood this very well. Conrad III's failure was God's judgement, and a new approach was needed. Thus Charlemagne appeared in Frederick's acts as sanctae memoriae already in 1152, though it is difficult to argue that any concrete plans were tied to Charlemagne's cult at this point (Koch 1972: 279; Friderici I. diplomata, vol. 1: 34). In 1158, one of Frederick's charters mentioned Charlemagne as sanctissimus for the very first time (Friderici I. diplomata, vol. 1: 351). The step was not undertaken immediately, however, nor was the sacralisation of Charlemagne a logical course of action in 1152-1155. It is notable, for example, that Henry IV (1056-1106), Frederick's great-grandfather, to whose reign Otto of Freising, in his Gesta Friderici (Gesta Friderici I.: 12-16, 22-25), dated all of the troubles of the realm,

\footnotetext{
${ }^{5}$ Elements of the Franco-Trojan legend already appeared in earlier sources, as in the work of Gregory of Tours (Libri Historiarum X: 57-58), but to my knowledge no scholar has discussed in any depth the reception of Trojan heritage in the Hohenstaufen courtly settings.
} 
seems to have had a similar conception of Charlemagne, though he apparently never pursued it further, and rather concentrated his ideological efforts on his stunningly huge cathedral in Speyer (Koch 1972: 102-103; Heinrici IV. diplomata, vol. 1: 367). ${ }^{6}$ The trigger for Charlemagne's further rise within the hierarchy of imperial ideology was the turbulent meeting at Sutri, where Frederick and Hadrian IV first met face to face on June 8, 1155, only a few days before Frederick's clash with the Roman ambassador. The issue at hand was a peculiar one: Frederick would not lead the pope's horse, nor would he hold the pope's stirrup while he ascended. Hadrian IV, whose name evoked Hadrian I, the first pope to grant the title of Roman patrician to Charlemagne (Becher 1999: 76-78), did not accept Frederick's flouting of this custom, which Lothair III upheld slightly more than twenty years ago (Holtzmann 1932: 308-309, 331-350). In the end, as Cardinal Boso (Les vies des papes: 391-392) wrote, after three days Frederick accepted the pope's terms, but only because reverence for Saint Peter was demonstrated by honouring the pope, and not because of the personage of Hadrian IV (Görich 2011: 241-246). Frederick, after all, was a deeply pious ruler whose attachment to the prince of the apostles was by no means negligible (Ciresi 2003: 94-102). ${ }^{7}$ This act, however, clarifies why Frederick's response to the Roman ambassador revolved around Charlemagne and Otto the Great: Frederick and his court now finally saw that the emperor must represent Charlemagne in order to uphold his authority against the Petrine authority of the popes.

Petersohn's doubts regarding the dating of the new ideological course of Frederick's court in 1155, on the other hand, seem to speak against this line of interpretation. The true difficulty lies, as is so often the case, in our lack of sources related to the key issues of medieval history. And yet an unanalysed source exists: the Cappenberg Head, whose commission Balzer recently dated to sometime between Frederick's coronation on June 18 and August of 1155, when Wibald of Stavelot set out for his journey to Constantinople. Its dating is based on attributing the iconography to Wibald of Stavelot and Provost Otto of

${ }^{6}$ For a different view of the debate over Speyer, see Sauerländer's article (Sauerländer 1973: 28-31).

7 For a contemporary account of Frederick's piety, see Rahewin's description (Gesta Friderici I.: 343); Saint Peter was present in the brachiary of Charlemagne (1164-1165) and very likely the reliquary shrine of Charlemagne (1183-1215), both objects being artworks commissioned by Frederick Barbarossa and pertaining to the imperial cult. 
Cappenberg, ${ }^{8}$ which does not leave room for other possibilities. Balzer set the date of the bust's completion before March 1156 (Balzer 2012: 254-263, 280$281,289-290)$. The head itself depicts an emperor within the walls of heavenly Jerusalem, which is carried by angels. ${ }^{9}$ It was once located on the hand of Godfrey of Cappenberg's relief statue, whence it looked up to the golden staurotheke which Frederick II of Swabia, Frederick Barbarossa's father, gave to the Cappenberg brothers in exchange for Otto of Cappenberg becoming his (as yet unborn) son's godfather (Balzer 2012: 254-263, 267-269). One of the greatest difficulties in explaining the bust was the problem of identity, as the sources clearly indicate that it was capud imperatoris. Grundmann's comparison of the head to Rahewin's 1159 description of Frederick Barbarossa (Gesta Friderici I.: 342-343), which was in turn largely assumed from Einhard's description of Charlemagne (Vita Karoli Magni: 26-27), led to the conclusion that the head was either Frederick Barbarossa or Charlemagne - or a combination of the two (Grundmann 1959: 50-61). While the sources can only be read as meaning that the head was that of Frederick Barbarossa, the head's moustache stems from Charlemagne's depictions in the Aquensian tradition (Nilgen 2010: 93-94). It was no surprise that Wibald of Stavelot, who was among the most important imperial courtiers under Lothair III, Conrad III, and Frederick Barbarossa, but also an abbot in the vicinity of Aachen, knew of the pictorial tradition of the great Frankish ruler in the vicinity of his abode (Uebach 2008: 50-70, 187-192).

The problem of the head's identity, however, does not seem unintentional. Rather, the true difficulty is why this was done. The answer can again be found only in Boso's account of the meeting between Hadrian I and Frederick I (Les vies des papes: 391-392), where the ruler had to treat a living pope just as he would Saint Peter. If one reverses this approach to apply to the imperial case, it immediately becomes obvious that had Frederick claimed to be representing Charlemagne, he would have done just the same as his rival, the pope. The Cappenberg Head, which merges the two emperors into one in a shining example of imperial piety, fits this description directly. Moreover, its sacral imagery, including angels supporting an emperor who looks up to the holy cross, is the first visual step toward a sacrum imperium iconography, as Nilgen

\footnotetext{
${ }^{8}$ This is not the Otto of Cappenberg to whom Frederick gave the Cappenberg Head and who was Godfrey of Cappenberg's brother, but rather his predecessor.

${ }^{9}$ For detailed analyses of the Cappenberg Head, see the works of Herbert Grundmann (Grundmann 1959), Hermann Fillitz (Fillitz 2010), Horst Appuhn (Appuhn 1973), and Caroline Horch (Horch 2013).
} 
dubbed the artistic features on the reliquary shrine of Charlemagne (1183-1215) and the stained-glass windows once located in the Romanesque Strasbourg Minster (1180s or 1190s) (Nilgen 2010: 88-90). Charlemagne and Otto the Great, the Franks and the Romans - they all formed parts of one complete ideological programme which served as a foundation for Frederick Barbarossa to put forth his claim to rule. This encompassed not only the three imperial realms of Germany, Burgundy and Italy, but also Rome, southern Italy and Sicily, where the chief opponents of the empire resided since the days of Henry IV, with whom the Gesta Friderici begins. As other scholars have already noted, Frederick supported an imperial identity, and did not employ a German national identity as a part of his ideology, though the court clearly saw itself as the East Frankish and/or German successors to the empire of Charlemagne.

A final point in the early years of Frederick Barbarossa's ideology is the emergence of the term sacrum imperium, which was to become an inseparable part of the empire's name under William of Holland (1247-1256) (Schwarz 2003: 237-240). After demonstrating how Charlemagne was gradually sanctified in the imperial ideology in 1152-1156, it seems difficult to see why a new term would suddenly appear, which after 1157 completely replaced the christus Domini, which was in use at Frederick's coronation in 1152 (Weinfurter 2005: 382). A closer reading of the Gesta Friderici, however, can provide a solution: just before Frederick wrote the letter which first uses the terms sacrum imperium and diva res publica in March 1157, the German-Byzantine alliance against the Normans of Sicily fell apart completely. In 1155-1156, Frederick, persuaded by the leaders of his army, returned to Germany without even invading the Kingdom of Sicily. The Byzantines under Paleologus, however, forged documents in Frederick's name and urged his southern Italian supporters to rise up against the Normans. This rebellion failed without achieving much, and the Byzantines merely conquered Bari for a short period (Gesta Friderici I.: 156-158). Frederick's letter which introduces the term sacrum imperium explicitly states that the emperor will not invade Sicily as the Greeks had invaded Apulia contrary to the GermanByzantine agreement and that the Milanese had grown bold and presumptuous in Italy (Gesta Friderici I.: 158). While Schwarz (Schwarz 2003: 86-89) recently quite convincingly suggested that the sacrum imperium stemmed from Otloh of Saint Emmeram, the traditional sanctity of the Byzantine emperors, their realm and all things imperial could have been transmitted in other ways as well. 
To find this other source, one has to look back to Frederick's first encounter with Byzantium: the Second Crusade. There, while the Crusaders laboured for Christ under miserable conditions under the burning sun of Anatolia, repeatedly suffering defeat and harassment by a people they thought were enemies of God, the illustrious emperor of the East, Manuel Komnenos, seemed more like a shadowy idol of the perfidious Greeks than the true Roman emperor he claimed to be (De profectione Ludovici VII: 76). Both the Germans and the French, who were by no means the best of allies, grew increasingly weary of their Byzantine ally, the loquaciousness of his ambassadors and his continuous failures to uphold his end of their bargains. As if this were not enough, Odo of Deuil even noted the response the Greek ambassadors gave to the Crusaders: all is allowed if it is for the good of the holy empire, the sacrum imperium (De profectione Ludovici VII: 56). Frederick Barbarossa, when writing about Byzantine affairs in 1157 to his fellow Crusader and leader of a large German force during the second crusade, Otto of Freising, did not intend to impress his uncle with fine words alone: by assuming a part of the ideology of his main rival for the mantle of the Roman emperors of old, Frederick let it be known that only he was a true Roman emperor, and that he would let this insult slide for the time being, but only because there were more pressing matters than another expedition against the Normans. Frederick might have been only buying time with his eloquence, but its effect endured. The Frankish legacy, which Frederick always held before him, was apparently not the only source of his ideology, nor was it always its governing element (Appelt 1967: 16).

In the end, the diet of Besançon in October 1157 would open up another wound in the imperial body. There the chancellor Rainald of Dassel read and translated the papal letter which stated that the emperor received the empire as a beneficium from the pope. When Rainald of Dassel translated this as a fief, the German magnates took umbrage. The papal ambassador, who may have been Orlando Bandinelli, the future Alexander III and one of Frederick's truest enemies, then responded defiantly: "From whom then does he have the empire, if not from our lord the pope?" (The Deeds of Frederick Barbarossa: 184), meaning that the emperor could not have obtained the empire in a different manner. Otto of Wittelsbach then tried to kill the ambassador when Frederick stopped him and protected his opponent. The tensions between the pope and the emperor ignited once again, and the insult of Sutri, along with knowledge of the existence of a fresco depicting Lothair III becoming a vassal of the pope and in return receiving the empire, became major political issues. Frederick then sent 
a brisk circular letter throughout his realm. In it, he claimed that the empire was given to him, God's anointed, by God alone through the election of the princes, and that Saint Peter himself said "Fear God, honour the king", and that the pope was perverting the doctrine of Saint Peter (Gesta Friderici I.: 173-179).

Frederick's Frankish identity was of no relevance on this occasion, it was God alone who could decide upon this matter of proximity to the divine. After receiving an exhortative letter from the pope as well, the bishops of Germany responded by sending him a letter, in which they repeated Frederick's doctrine of God alone granting the empire to the emperor through the princes, though they accepted that the pope had the right to perform the imperial consecration (Gesta Friderici I.: 185-189). Unlike their ruler, they did not dispute Pope Hadrian IV's Petrine orthodoxy, nor did they change the essence of the argument: the emperor had no intermediary before God even though the pope crowned him. The reason why no national or group identity emerged in this dispute is very simple: the pope did not deny that the empire belonged to Frederick or the Germans even though he disputed the manner in which the emperors received the imperium, therefore the Germans did not need to defend their right to the empire, but only the manner in which it was granted to them. In 1158, long before the momentous diet of Roncaglia, Frederick already took another step in the sacralisation of his reign by calling the magnates fideles domini dei ac sacratissimi imperii in his charters, thereby declaring both himself and the imperial princes the vassals of God, who was the mystical ruler of the empire (Koch 1972: 279; Friderici I. diplomata, vol. 1.: 351). Finally, the same year saw Frederick calling Charlemagne sanctissimus, a momentous achievement for Charlemagne's most devout worshipper, who was to canonise his predecessor seven years later (Koch 1972: 279; Petersohn 1975).

The first six years of Frederick's reign saw the sacralisation of the empire and of Charlemagne: the emperor became both God's anointed and a representative of Charlemagne at the same time when the Franks were given a divine mission of ruling a holy Roman empire due to their virtue, which was first exemplified by Charlemagne, and then by Otto the Great. The FrankishCarolingian cult virtually occupied the entire ideological hierarchy under the early Frederick Barbarossa, and there seems not to have been much space left for other cults, such as that of the saintly Henry II, regardless of his relevance under Conrad III, or precisely due to Conrad's failure under Henry's auspices. All this ensured Frederick's continued power and his consolidation of disparate identities 
to create an ideological grip at the onset of his rule which lasted for the remainder of his reign.

\section{Bibliography}

\section{Primary Sources - Diplomata}

Heinrich Appelt, ed., Friderici I. diplomata, 5 vol., Hannover 1975-1990.

Dietrich von Gladiss and Alfred Gawlik, ed., Heinrici IV. diplomata, 3 vol., Hannover 1941-1978.

Primary Sources - Narrative Sources

Benzo of Alba, Ad Heinricum IV.imperatorem libri VII, ed. and trans. Hans Seyffert, Hannover 1996.

Boso, "Les vies des papes," in: Le Liber Pontificalis, ed. Louis Duchesne, Paris 1886-1892, vol. 2, 353-446.

Einhard, Einhardi Vita Karoli Magni, ed. Georg Heinrich Pertz and and Georg Waitz, Hannover 1911.

Godfrey of Viterbo, "Pantheon," in: Historici Germaniae saec. XII, 2 (ed. Georg Heinrich Pertz and and Georg Waitz), Hannover 1872, 107-307.

Gregory of Tours, Libri Historiarum X, ed. Bruno Krusch and William Levison, $2^{\text {nd }}$ ed., Hannover 1951.

Odo of Deuil, De profectione Ludovici VII in orientem: The Journey of Louis VII to the East, ed. and trans Virginia Gingerick Berry, New York 1948.

Otto of Freising, Chronica sive historia de duabus civitatibus, ed. Adolf Hofmeister, Hannover 1912, reprint 1984.

Otto of Freising and Rahewin of Freising Ottonis et Rahewini Gesta Friderici I. imperatoris, ed. Georg Waitz and Bernhard von Simson, Hannover 1884, reprint 1997.

Otto of Freising, and Rahewin of Freising, The Deeds of Frederick Barbarossa, ed. and trans. Charles Mierow, New York 1966.

Pseudo-Fredegar, "Chronicarum quae dicuntur Fredegarii Scholastici libri IV. Cum Contituationibus," in: Fredegarii et aliorum Chronica. Vitae sanctorum (ed. Bruno Krusch), Hannover 1888, 18-193.

Suger, "Vie de Louis le Gros, par Suger." in: CEuvres complètes de Suger (ed. Alfred Lecoy de La Marche), Paris 1867, 1-150. 


\section{Secondary Sources}

APPELT 1967

Heinrich Appelt, "Die Kaiseridee Friedrich Barbarossas," Sitzungsberichte der Österreichischen Akademie der Wissenschaften, philosophischhistorische Klasse, 252/4, Vienna, 1967, 1-32.

APPUHN 1973

Hörst Appuhn, "Beobachtungen und Versuche zum Bildnis Kaiser Friedrichs I. Barbarossa in Cappenberg," Aachener Kunstblätter, 44, Aachen 1973, 129-192.

\section{BECHER 1999}

Matthias Becher, Karl der Große, Munich 1999.

BOURNAZEL 1986

Eric Bournazel, "Suger and the Capetians," in: Abbot Suger and SaintDenis (ed. Paula Lieber Gerson), New York 1986, 55-72.

BRÜHL 1995

Carlrichard Brühl, Deutschland - Frankreich: Die Geburtzweier Völker, Cologne 1995.

CIRESI 2003

Lisa Victoria Ciresi, Manifestations of the Holy as Instruments of Propaganda: The Cologne Dreikönigenschrein and the Aachen Karlsschrein and Marienschrein in Late Medieval Ritual, Rutgers University 2003.

ENGELS 1988

Odilo Engels, "Des Reichesheiliger Gründer: Die Kanonisation Karls den Großen und ihre Beweggründe," in: Karl der Große und sein Schrein in Aachen: Eine Festschrift (ed. Hans Müllejans), Aachen 1988, 37-46.

FILLITZ 2010

Hermann Fillitz, "Der Cappenberger Barbarossakopf," in: Thesaurus mediaevalis: Ausgewählte Schriften zur Schatzkunst des Mittelalters (ed. Franz Kirchwegerand Werner Telesko), Ostfildern 2010, 115-126.

\section{GIESEBRECHT 1855-1895}

Wilhelm von Giesebrecht, Geschichte der deutschen Kaiserzeit, 6 vol., Leipzig 1855-1895.

\section{GOEZ 2000}

Werner Goez, Kirchenreform und Investiturstreit 910-1122, Stuttgart 2000. 
GÖRICH 2011

Knut Görich, Friedrich Barbarossa: Eine Biographie, Munich 2011.

GRUNDMANN 1959

Herbert Grundmann, Der Cappenberger Barbarossakopf und die Anfänge des Stiftes Cappenberg, Cologne 1959.

HAMPE 1935

Karl Hampe, Hanns Naumann, Hermann Aubinet al., ed., Karl der Große oder Charlemagne?, Berlin 1935.

HAYWARD 1981

Jane Hayward, "Stained Glass at Saint-Denis," in: The Royal Abbey of Saint-Denis in the Time of Abbot Suger (1122 - 1151) (ed. Sumner McKnight Crosby, Jane Hayward, Charles T. Little and William D. Wixom), New York 1981, 61-100.

HEHL 1999

Ernst-Dieter Hehl, "Kreuzzug - Pilgerfahrt - Imitatio Christi," in: Pilger und Wallfahrtstätten in Mittelalter und Neuzeit (ed. Michael Matheus), Stuttgart 1999, 35-51.

HOLTZMANN 1932

Robert Holtzmann, "Zum Strator- und Marschalldienst: Zugleicheine Erwiderung," Historische Zeitschrift, 145/2, Munich/Berlin 1932, 301350.

HORCH 2013

Caroline Horch, "Nach dem Bild des Kaisers": Funktionen und

Bedeutungen des Cappenberger Barbarossakopfes, Cologne 2013.

KOCH 1972

Gottfried Koch, Auf dem Wege zum Sacrum Imperium: Studien zur ideologischen Herrschaftsbegründung der deutschen Zentralgewalt im 11. und 12. Jahrhundert, Cologne 1972.

\section{MÜLLER-MERTENS 1970}

Eckhard Müller-Mertens, Regnum Teutonicum, Berlin 1970.

NILGEN 2010

Ursula Nilgen, "Staufische Bildpropaganda: Legitimation und Selbstverständnis im Wandel," in: Die Staufer und Italien: Drei Innovations regionen im mittelalterlichen Europa, (eds. Alfried Wieczorek, Bernd Schneidmüller and Stefan Weinfurter), Stuttgart 2010, vol. 1, 87-96. 


\section{PETERSOHN 2010}

Jürgen Petersohn, Kaisertum und Rom in spätsalischer und staufischer Zeit: Romidee und Rompolitik von Heinrich V. bis Friedrich II., Hannover 2010.

\section{PETERSOHN 1975}

Jürgen Petersohn, "Saint-Denis - Westminster - Aachen: Die KarlsTranslatio von 1165 und ihre Vorbilder," Deutsches Archiv für Erforschung des Mittelalters, 31, Cologne 1975, 420-454.

RANKE 1811-1888

Leopold von Ranke, Weltgeschichte, 8 vol., Leipzig 1881-1888.

SAUERLÄNDER 1973

Willibald Sauerländer, "Cluny und Speyer," in: Investiturstreit und Reichsverfassung (ed. Josef Fleckenstein), Sigmaringen 1973, 9-32.

SCHWARZ 2003

Jörg Schwarz, Herrscher- und Reichstitelbei Kaisertum und Papsttum im 12. und 13. Jahrhundert, Cologne 2003.

\section{TELLENBACH 1943}

Gerd Tellenbach, "Von der Tradition des fränkischen Reiches in der deutschen und französischen Geschichte des hohen Mittelalters," in: Der Vertrag von Verdun 843: 9 Aufsätze zur Begründung der europäischen Völker- und Staatenwelt (ed. Theodor Mayer), Leipzig 1943, 181-202.

\section{TELLENBACH 1988}

Gerd Tellenbach, Die westliche Kirche vom 10. Bis zum frühen 12. Jahrhundert, Göttingen 1988.

UEBACH 2008

Christian Uebach, Die Ratgeber Friedrich Barbarossas (1152 - 1167), Marburg 2008

WEINFURTER 2005

Stefan Weinfurter, "Wie das Reich heilig wurde," in: Gelebte Ordnung, gedachte Ordnung: Ausgewählte Beiträge zu König, Kirche und Reich (ed. Stefan Weinfurter), Ostfildern 2005, 361-384. 